\title{
PENERAPAN GREEN BUILDING DI PERKANTORAN MENARA SUARA MERDEKA, SEMARANG
}

\author{
Soraya Rizky Nabilla*1, Suzanna Ratih Sari², Titien Woro Murtini ${ }^{3}$ \\ 1Universitas Diponegoro Semarang, ${ }^{2}$ Universitas Diponegoro Semarang, \\ 3Universitas Diponegoro Semarang \\ e-mail: *1sorayanabilla@gmail.com,2ratihsaris@yahoo.com, 3titin_wm@yahoo.com
}

\begin{abstract}
Abstrak_Perancangan bangunan yang tepat dapat mengurangi kerusakan lingkungan serta mengurangi konsumsi energi saat proses pembangunan maupun saat gedung telah beroperasi. Perancangan dengan pendekatan iklim dan konsep green building berpengaruh terhadap konservasi energi terutama energi listrik. Menara Suara Merdeka merupakan perkantoran green building pertama di kota Semarang. Dalam proses pembangunan green building, diperlukan ahli yang berpengalaman merencanakan, membangun, dan merawat bangunan. Melihat beberapa fakta tersebut, perlu diadakan penelitian mengenai penerapan Green Building di Gedung Menara Suara Merdeka. Tujuan penelitian ini berguna untuk mengetahui sejauh mana konsep Green Building diimplementasikan dalam bangunan, dan memberi rekomendasi apabila ada aspek green building yang belum terpenuhi. Optimalisasi penerapan Green building jika bernilai kuat dapat dijadikan referensi selanjutnya pembangunan gedung perkantoran berkonsep Green Building di Indonesia. Metode penelitian dengan pendekatan kualitatif rasionalistik. Dari hasil penelitian menunjukkan bahwa pemilik bangunan memiliki komitmen kuat dalam mewujudkan bangunan ramah lingkungan. Hal ini didukung dengan arsitek, dan kontraktor yang berpengalaman dalam mewujudkan green building. Pengguna gedung berperan dalam perilaku hijau yang mendukung penghematan penggunaan energi. Penerapan Green Building yaitu: gedung parkir hemat energi, fasad serta tata bangunan yang menyesuaikan keadaan iklim, AC Variable Refrigerant Volume, pemanfaatan air limbah daur ulang, perlengkapan sanitair hemat air, peningkatan produktifitas kinerja, dan konstruksi berkelanjutan.
\end{abstract}

Kata kunci: Green Building; Menara Suara Merdeka; Konservasi Energy.

\begin{abstract}
An appropriate building design can reduce both in environmental damage and energy consumption during the construction process and even the building is doing operationally. The design with a climate approach and the concept of green building has an effect on energy conservation, especially electricity. Suara Merdeka Tower is the first green building office in Semarang city. In the process of establishing green buildings, needs experts who experienced in planning, building and maintaining buildings. From some of these facts, it is necessary to conduct a research toward the application of Green Building in the Suara Merdeka Tower Building. The purpose of this study is to find how far the Green Building concept is implemented in buildings, and to provide recommendations if there are aspects of green building that have not been fulfilled. Optimizing the application of Green building; if has strong value, it can be used as a next reference in establishing the office building with the Green building concept in Indonesia. The Research method was a rationalistic qualitative approach. The results of the study showed that building owners have a strong commitment to realizing environmentally friendly buildings. This is supported by its architects, and its contractors who are experienced in realizing green building. Building users play a role in green behavior that supports saving energy use. The applications of the Green Building are: energy-efficient parking buildings, facades and building arrangements that adjust climate conditions, Volume Refrigerant Variable AC, utilization of recycled wastewater, water saving sanitary equipment, increased performance productivity, and sustainable construction.
\end{abstract}

Keywords: Green Building; Suara Merdeka Tower; Energy Conservation.

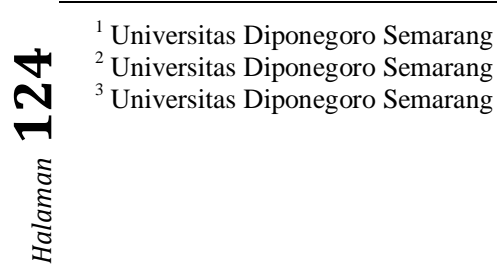




\section{PENDAHULUAN}

Proses pembangunan seringkali kurang memperhatikan kesinambungan dengan alam, dalam hal pemanfaatan iklim, sumberdaya alam, penggunaan teknologi yang tidak ramah terhadap alam. Oleh karena itu, perancangan bangunan secara arsitektur mempunyai andil besar memicu pemanasan global. Pemanasan global seringkali dikaitkan dengan bangunan (F. Heinz, dan Suskiyatno 2007). Proses konstruksi pada tahap pelaksanaan pembangunan sampai pada saat bangunan dimanfaatkan juga dapat berdampak negatif pada lingkungan di sekitar bangunan tersebut. Untuk itu diperlukan upaya rancangan arsitektur pendekatan Green Building. Green building adalah bangunan yang sedikit mengonsumsi sumber daya alam, ternasuk energi, air, dan material, serta sedikit menimbulkan dampak negatif bagi lingkungan sekitar (Karyono 2010).

Pada Desember 2013, mulai beroperasi Gedung Menara Suara Merdeka sebagai gedung jasa dan sewa perkantoran dengan konsep green building pertama di kota Semarang. Berdasarkan latar belakang tersebut perlu diketahui latar belakang pemilik membangun green building dan penerapannya di Menara Suara Merdeka. Menara Suara Merdeka berlokasi di Jalan Pandaran Semarang. Jalan Pandanaran merupakan Central Business Distric yang terletak pada Bagian Wilayah Kota I merupakan kawasan yang memiliki fungsi sebagai wilayah perkantoran, perdagangan, dan jasa. Fungsi Menara Suara Merdeka sebagai gedung perkantoran yang dihuni oleh bermacammacam tenant kantor penyewa. Jam aktif kegiatan operasional gedung dimulai pada pukul 08.00 hingga pukul 17.00 WIB, para karyawan sebagai pengguna bangunan yang berkantor di Menara Suara Merdeka setiap hari selama 5 hari kerja dalam seminggu, menghabiskan waktu per hari 9 jam di kantor dan menjadikan kantor sebagai rumah kedua. Dengan kegiatan selama 9 jam per hari di kantor tersebut, karyawan bekerja dengan media komputer ataupun laptop yang membutuhkan energi listrik, pencahayaan yang membutuhkan energi listrik. Dengan banyaknya kebutuhan akan energi listrik, air, maka akan tepat jika gedung perkantoran khususnya yang berlantai banyak, dapat menerapkan konsep green building agar mendukung penghematan energi, kenyamanan dan keamanan pengguna bangunan.

Penelitian sebelumnya mengenai Konsep Green Building Pada Bangunan Kantor (Studi Kasus: Spazio Office, Surabaya) yang dilakukan oleh Annisa Fikriyah Tasya dan Ary Deddy Putranto, diketahui bahwa Kantor Spazio termasuk dalam green building menurut Green Building Council Indonesia dengan peringkat bangunan Silver yang telah memenuhi 53 poin penilaian dari total poin 117 menurut sistem rating GBCI (T.A. Fikriyah 2016). Namun pada penelitian tersebut tidak membahas mengenai pengalaman dari owner, arsitek, kontraktor, dan karyawan kantor. Pada penelitian ini selain membahas fisik bangunan juga membahas mengenai pandangan dan pengalaman dari owner, arsitek, kontraktor, dan karyawan kantor mengenai green building. Tujuan penelitian ini berguna untuk mengetahui sejauh mana konsep Green Building diimplementasikan dalam bangunan, dan memberi rekomendasi apabila ada aspek green building yang belum terpenuhi. Jika konsep green guilding di Gedung Menara Suara Merdeka berhasil, maka dapat dijadikan referensi selanjutnya pembangunan gedung perkantoran berkonsep green building di Indonesia.

\section{METODE}

Mengacu pada jenis penelitian yang dilakukan bahwa penelitian bermaksud untuk mengetahui penerapan green building di Gedung Menara Suara Merdeka dan memberi rekomendasi apabila ada aspek green building yang belum terpenuhi. Penelitian ini menggunakan metode penelitian kualitatif dengan pendekatan rasionalistik. Metode penelitian kualitatif rasionalistik dimulai dari pendekatan holistic berupa grand concepts, diteliti pada obyek spesifik, 
dan didudukkan kembali hasil penelitian dengan grand concepts tersebut (Muhadjir 2000). Cara menganalisa konsep green building berpedoman pada parameter Greenship Exsiting Building versi 1.1 dari Green Building Council Indonesia sebagai grand concepts. Terdapat 6 parameter Green Building yaitu tepat guna lahan, konservasi energi, konservasi air, sumber dan siklus material, kesehatan dan kenyamanan ruang, dan sistem pengelolaan bangunan.

Pada proses pengumpulan dan analisa data menggunakan pendekatan kualitatif dengan wawancara informan yaitu pemilik gedung, arsitek, kontraktor, karyawan gedung, observasi, dan pengukuran lapangan. Dari hasil wawancara dan observasi kemudian dipadukan dengan parameter Greenship Exsiting Building versi 1.1 dari Green Building Council Indonesia sehingga didapatkan tema pembahasan penelitian. Lokasi penelitian berada di Jl. Pandanaran No. 30 Semarang, Jawa Tengah.
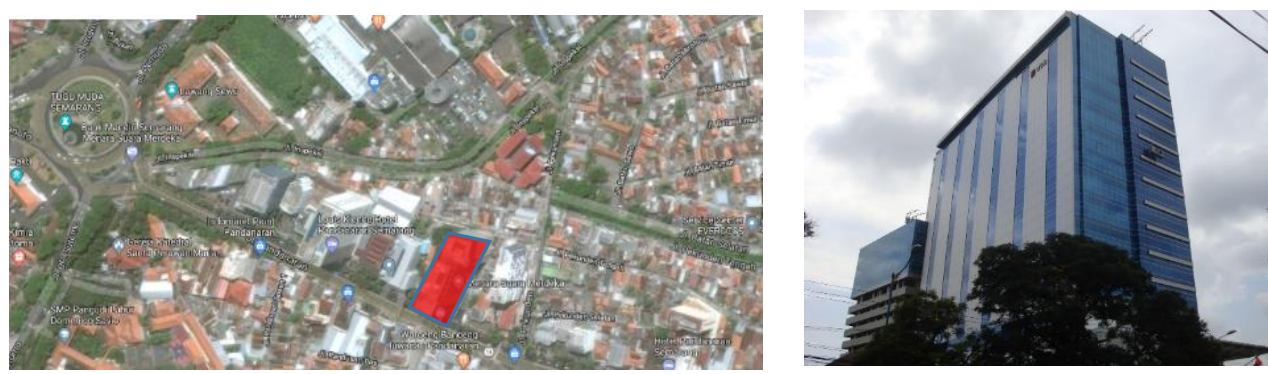

Gambar 1 : Lokasi Menara Suara Merdeka

Sumber: https://www.google.com/maps/place/Menara+Suara+Merdeka

\section{HASIL PEMBAHASAN}

Latar belakang pemilik memanfaatkan perkantoran green building adalah mewujudkan bangunan yang ramah lingkungan, yang meminimalkan dampak kerusakan lingkungan. Alasan kedua mewujudkan bangunan yang "high end" sehingga menarik minat pembeli gedung untuk menaikkan nilai properti. High end dalam istilah bidang properti ialah menawarkan bangunan dengan kualitas yang terbaik. Alasan ketiga yaitu mengurangi biaya operasional gedung. Konsultan perencana dari Menara Suara Merdeka telah berpengalaman merancang gedung dengan konsep green building. Sedangkan kontraktor merupakan anggota dari Green Building Council Indonesia. Tercapainya green building pada perkantoran sejak awal perencanaan, proses pembangunan, dan penggunaan gedung atas kerjasama yang baik dari pemilik gedung, perencana (arsitek gedung), pelaksana (kontraktor gedung), pengelola bangunan, dan pengguna bangunan (karyawan gedung).

\section{A. Eksterior}

Pengoptimalan efisiensi energi bangunan terkait dengan desain arsitektur yang hemat energi. Jika bangunan sejak awal dirancang dengan pendekatan hemat energi, maka akan terjadi keunggulan efisiensi energi saat gedung telah digunakan.

\section{Bentuk dan massa bangunan}

Massa banguan disesuaikan dengan bentuk tapak yang memanjang, orientasi tapak, dan peraturan bangunan. Bentuk tapak memanjang dengan ukuran 94 x 31 meter dengan arah tapak menghadap jalan utama yaitu Jalan Pandanaran. Optimasi bentuk bangunan pada daerah iklim tropis dengan perbandingan lebar : panjang adalah 1:3 supaya bangunan mendapatkan ventilasi silang (Yeang 1994). Menara Suara Merdeka berbentuk slab shape dengan bangunan yang memanjang dan tipis. Cara mendesain bangunan agar hemat energi dengan bentuk massa bangunan memanjang dan tipis untuk memaksimalkan pencahayaan dan menghemat energi listrik (Vale 1991). Bentuk massa bangunan Menara Suara Merdeka slab shape yang memanjang dan tipis, didukung dengan fasad berupa kaca sehingga sinar 
matahari alami dapat masuk ke dalam ruangan dan dapat menghemat penggunaan pencahayaan buatan.

\section{Orientasi Bangunan}

Orientasi bangunan mengikuti bentuk tapak dengan memanjang ke utara dan selatan, dan menghadap ke selatan yaitu menghadap ke jalan utama Jalan Pandanaran. Keterbatasan lahan dan sisi kanan kiri tapak yang telah terisi bangunan menjadi alasan gedung tidak dapat berorientasi memanjang ke arah timur dan barat. Sisi panjang bangunan menghadap ke arah timur dan barat, sehingga pada fasad timur dan barat diperlukan shading berupa material khusus untuk mengurangi sinar matahari yang masuk ke dalam bangunan.

$\mathrm{U}$
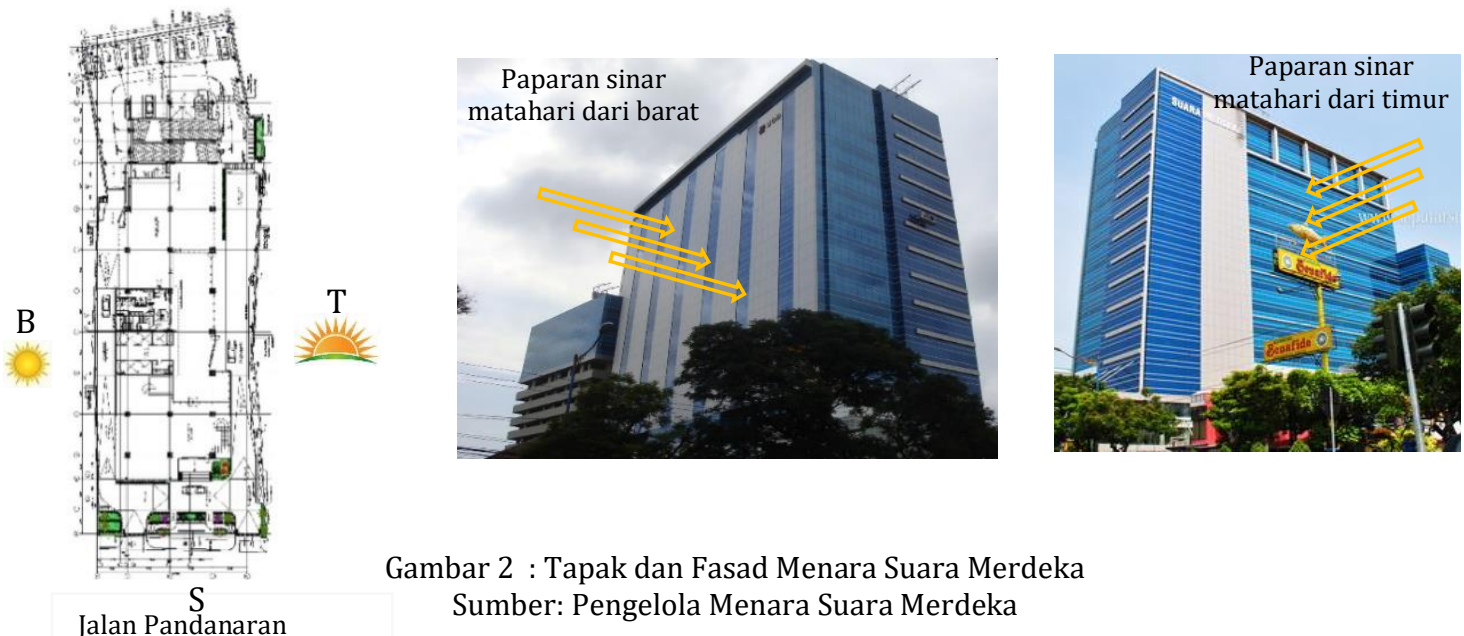

Gambar 2 : Tapak dan Fasad Menara Suara Merdeka

Sumber: Pengelola Menara Suara Merdeka

\section{Fasad}

Bangunan multi fasad, yaitu keempat fasad diolah dengan tampilan berbeda. Fasad gedung didominasi oleh curtain wall (dinding tirai) dan Alumunium Composit Panel (ACP). Jenis kaca pada fasad merupakan jenis kaca stopsol atau lebih dikenal dengan reflective glass merupakan kaca yang dilapisi logam untuk meningkatkan refleksi panas dan cahaya, sehingga mengurangi panas yang masuk ke dalam bangunan. Menurut arsitek Menara Suara Merdeka, jenis kaca dipilih dengan kriteria kemampaun jarak pandang mata manusia (visibility), tidak silau dalam memantulkan cahaya, dan pemilihan warna kaca yang sejuk dipandang mata. Kaca pada fasad adalah kaca stopsol berwarna biru. Fasad kaca bangunan berlantai banyak sebaiknya berwarna teduh seperti biru atau hijau daripada warna keras seperti abu-abu yang dapat menimbulkan efek silau (Wibisono 1999).

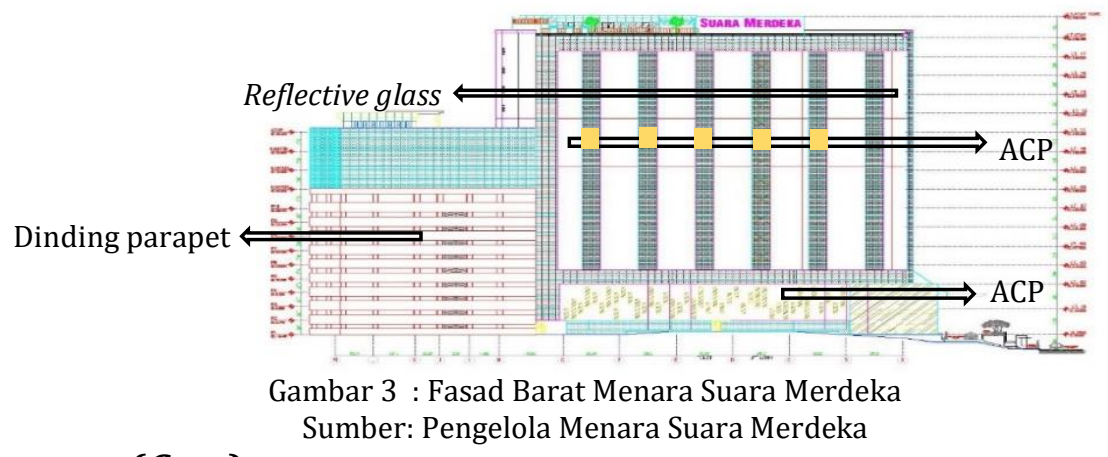

\section{Inti bangunan (Core)}

Inti bangunan atau core merupakan tempat untuk meletakkan transportasi vertikal dan distribusi energi seperti lift, tangga, kamar mandi, dan shaft mekanis. Terdapat dua 
buah core dengan tipe double core di sisi barat dan utara. Ruang-ruang servis dan tangga dengan dinding masif dapat diletakkan di sisi barat dan timur, sehingga dapat berfungsi sebagai thermal buffer zones. Pada sisi luar core bagian barat, diberi finishing Alumunium Composit Panel untuk melindungi core dari paparan sinar matahari.

\section{B. Interior}

Penataan ruang kantor dengan sistem open layout yaitu penataan ruang kantor tidak menggunakan penyekat ruang permanen. Perencanaan ruang dan fasilitas pada green office memiliki prinsip menghemat ruang, sehingga akan menghemat dalam penggunaan material. Penghapusan partisi pembatas memaksimalkan komunikasi terbuka antar karyawan. Pertimbangan penataan sistem interior kantor mempertimbangkan fleksibilitas. Yaitu perencanaan harus mempertimbangan perubahan di masa mendatang sehingga mendukung keberlanjutan. Misalnya perubahan penyewa, atau penyewa yang ingin merenovasi ruang kantor di dalamnya. Dengan bentuk denah yang memanjang dan pola linear, serta dengan banyaknya bukaan-bukaan kaca di setiap bagian ruang kantor, memaksimalkan pencahayaan alami masuk ke dalam ruangan. Pola ruang linear mendukung keberlanjutan karena tiap ruang memiliki hubungan langsung dengan lingkungan luas (Mediastika 2013). Akses penglihatan ke luar bangunan juga dapat maksimal dengan penggunaan curtain wall sehingga meningkatkan efek psikologi seseoarang yang memungkinkan karyawan bekerja tanpa tekanan.
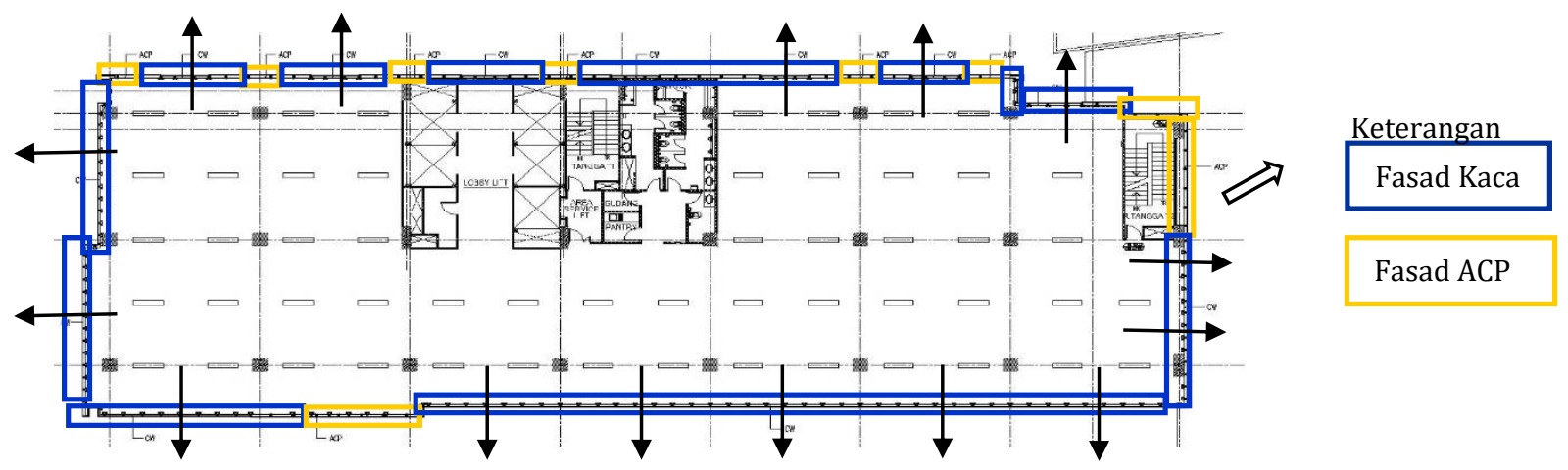

Gambar 4 : Denah Menara Suara Merdeka Sumber: Pengelola Menara Suara Merdeka

Pada setiap lantai kantor, terdapat sebuah koridor memanjang yang membagi dua ruang penyewa. Kedalaman ruang pada gedung termasuk tipe depth space. Yaitu jarak antara koridor dengan bagian terluar bangunan yaitu 11 - 19 meter (Manasseh, Leonard dan Cunliffe 1962). Ruang-ruang pada kedalaman ini dapat dibagi menjadi beberapa ruang yang lebih kecil. Pembagian ruang yang lebih kecil dengan partisi diserahkan kepada penyewa sesuai dengan kebutuhan sehingga mendukung konsep desain berkelanjutan yang dapat membantu perubahan perencanaan ruang di masa kini dan masa yang akan datang.

\section{Tepat guna lahan}

\section{Aksesibilitas komunitas}

Letak gedung berdekatan dengan 14 fasilitas umum, dengan jarak pencapaian kurang dari 1000 meter memudahkan mobilitas karyawan dengan berjalan kaki dengan jalur pedestrian yang baik, dapat mengurangi pemakaian kendaraan bermotor. Pengukuran jarak fasilitas umum menggunakan alat berupa GPS (Global Positioning System ). Letak halte Bus Transit Rapid (BRT) tepat di depan gedung hanya dalam jarak 5 meter dari gerbang gedung.

Jalur pedestrian di sepanjang Jl. Pandanaran telah tertata dengan baik oleh 
kenyamanan bagi pengguna jalan sehingga pengguna jalan merasa aman, mudah, bebas hambatan berjalan di pedestrian. Jalur pemandu untuk masyarakat disabilitas berada di tengah jalur pedestrian dengan ubin bertekstur garis-garis dan warna kuning. Ukuran ubin jalur pemandu adalah 30x30 cm, dengan tekstur garis yang memiliki tinggi $0,5 \mathrm{~cm}$ sesuai dengan Permen PU No. 30/PRT/M/2006 mengenai jalur pemandu (Kementrian Pekerjaan Umum RI 2006).

Jika memungkinkan, penyediaan fasilitas pendukung dapat direncanakan dalam sebuah gedung untuk memudahkan aksesibilitas. Contohnya adalah penyediaan kantin untuk karyawan, bank, serta tempat ibadah. Pada gedung Menara Suara Merdeka, dilengkapi dengan adanya cafe dan bank di lantai 1 , serta adanya tempat ibadah berupa mushola karyawan, sehingga memudahkan aksesibilitas karyawan gedung dalam mencapai fasilitas pendukung tersebut.

\section{Gedung parkir hemat energi}

Gedung parkir hemat energi harus memiliki pencahayaan, sirkulasi udara yang baik untuk membuang asap dari kendaraan, dan mudah untuk manuver kendaraan. Ketersediaan unit parkir mobil telah dibatasi namun tetap cukup untuk mengakomodasi kebutuhan parkir. Perbandingan ketersediaan parkir yaitu 1:100. Artinya bahwa setiap luas tenant $100 \mathrm{~m}^{2}$, memiliki 1 unit parkir. Terdapat 200 unit tempat parkir mobil dan 500 unit tempat parkir motor dalam gedung parkir. Kebijakan tarif parkir mobil dan motor fluktuatif per jam.

Pola parkir kendaraan dua sisi dengan sudut $90^{\circ}$ dengan sirkulasi satu arah. Lebar ruang parkir mobil berukuran 2,4 x 5,3 meter, dengan lebar sirkulasi 5,8 meter. Ukuran ruang parkir tersebut telah memenuhi standart ruang parkir ukuran 2,3 x 5 meter (Neufert 2002). Terdapat car stopper dan garis parkir sebagai penanda kendaraan untuk keselamatan pengguna. Menurut pegawai kontraktor, pembuatan car stopper menggunakan prinsip reuse, yaitu sisa dari cor beton saat hari itu, dengan volume kurang dari $1 / 2 \mathrm{~m}^{3}$, digunakan untuk mencetak car stopper dan perataan jalan depan gedung.

\section{Lansekap pada Lahan}

Luas taman hijau pada lantai dasar (Ground floor) sebesar 98,89 $\mathrm{m}^{2}$. Sedangkan luas lahan total adalah $2.997 \mathrm{~m}^{2}$. Terdapat green roof di lantai 2 dan 17, tanaman dapat menyerap karbon dioksida (CO2) yang berasal dari emisi kendaraan karena tapak berada di Jalan Arteri Sekunder yang dilalui banyak kendaraan. Pada kawasan atau lahan dengan kepadatan tinggi dengan lahan yang sangat terbatas, ruang terbuka hijau dapat disediakan pada atap bangunan yang disebut taman atap (green roof). Atap green roof memiliki manfaat sebagai lahan resapan air, pengatur iklim mikro, menambah estetika. Selain itu, green roof dapat sebagai area sosialisasi untuk melepas penat para karyawan kantor. Menurut arsitek, green roof yang berada di lantai 2 dirancang untuk estetika, dan green roof tersebut dapat terlihat dari Jalan Pandanaran.

\section{Konservasi Energi}

\section{Pengkondisian udara buatan}

AC Variable Refrigerant Volume (VRV) menggunakan kompresor inverter dengan sensor gerak untuk menyesuaikan kapasitas pendingin dengan memperlambat atau mempercepat kompresor. Keistimewaan dari AC VRV ini dalam satu unit outdoor AC dapat memiliki maksimal 29 unit indoor AC. Dengan teknologi AC VRV ini, dapat menghemat 2030\% energi listrik (Satwiko 2008).

\section{Peralatan ME hemat energI}

Dalam memonitor kinerja AC VRV, terdapat softaware Intelegent Manager yang terpasang pada komputer pengelola. Pada aplikasi Intelligent Manager, dapat terlihat bagian AC mana saja yang hidup, mati, ataupun rusak. AC secara otomatis dapat dimatikan 
dengan aplikasi ini. Namun pihak pengelola tidak memiliki wewenang untuk mematikan AC secara otomatis. Karena kinerja AC sepenuhnya diserahkan kepada tenant penyewa gedung. Building Automatic System (BAS) yaitu pemrograman komputer yang secara otomatis memonitor dan mengontrol pemakaian utilitas. Lampu gedung menggunakan automatic time switch. Hand dryer hemat energi yang dapat mengeringkan tangan dalam waktu 12 detik, dengan penggunaan energi listrik 510 Watt (hand dryer tipe lama membutuhkan waktu 30 detik untuk mengeringkan tangan dan mengkonsumsi 1800 watt).

\section{Konsumsi energi listrik}

Pihak pengelola mengedukasi kepada tenant mengenai penghematan listrik. Salah satunya dengan menerapkan $\mathrm{KWH}$ double tarif. Yaitu terdapat pembagian antara perhitungan konsumsi energi listrik saat waktu beban puncak (WBP) dan saat luar waktu beban puncak (LWBP). Rata-rata pemakaian listrik per bulan adalah $297 \mathrm{kwh} / \mathrm{m} 2 /$ tahun. Standar acuan konsumsi energi listrik untuk gedung perkantoran adalah 250 $\mathrm{kWh} / \mathrm{m} 2 /$ tahun (GBCI 2016). Bulan Juli 2017 dan Desember 2017 pemakaian paling tinggi karena karyawan bekerja lembur menjelang lebaran dan libur akhir tahun. Saat karyawan melakukan kegiatan lembur, hanya menyalakan listrik seperlunya saja, yaitu dalam 1 ruangan yang digunakan untuk lembur saja.

Kegiatan lembur di kantor mengakibatkan bertambahnya konsumi energi listrik dalam penggunaan komputer, printer, lampu, mesin fotokopi dan AC. Saat lembur di malam hari, terdapat aktifitas makan dan minum yang menggunakan alat penunjang yaitu dispenser. Alat utilitas tersebut dapat dikurangi penggunaannya ketika lembur. Penggunaan lift dapat dikurangi menjadi 1 lift yang aktif saat ada kegiatan lembur. Suhu AC diatur $25^{\circ} \mathrm{C}$ atau bahkan dimatikan saat lembur di malam hari. Penggunaan lampu dikurangi dengan hanya menyalakan lampu pada ruangan yang digunakan untuk lembur. Penggunaan kamar mandi dapat dibatasi sehingga menghemat penggunaan air dan lampu.

Alternatif sumber energi listrik berasal dari energi matahari (energi surya). Menara Suara Merdeka memiliki daya listrik sebesar $2.770 \mathrm{kvA}$ yang termasuk ke dalam golongan tarif listrik bisnis besar dengan tegangan menengah (TM). Apabila direncanakan solar panel di atap gedung dengan luas 110,74 $\mathrm{m}^{2}$, maka jumlah solar panel yang dapat dipasang sebanyak 59 buah. Dari 59 buah solar panel berkapasitas $300 \mathrm{~W}$, dapat menghasilkan energi listrik $73 \mathrm{kwh} /$ hari dan $26.635 \mathrm{kwh} /$ tahun.

\section{E. Konservasi Air}

\section{Daur ulang air dan kualitas air}

Daur ulang air limbah diolah menjadi layak pakai dengan teknologi STP (sewage treatment plant) berbasis biotec system untuk penyiraman taman. Kualitas air rutin dipantau oleh Badan Lingkungan Hidup. Pengolahan air dari STP telah layak untuk digunakan sebagai air minum, namun peruntukkan air olahan ini hanya digunakan untuk penyiraman tanaman. Kualitas air yang tersedia di gedung sangat bersih.

\section{Efisiensi air kran dan penghematan air}

Wastafel otomatis dengan sinar infra merah dengan laju 5,8 liter/menit. Pada closet gedung menggunakan sistem pembilasan menggunakan sistem dual flush. Dual flushing toilet menggunakan perbadingan (3/6 L), yaitu 3 liter air untuk tombol kecil,dan 6 liter air untuk tombol besar. Untuk single flushing toilet tipe lama, mengeluarkan volume air sebanyak 13,6 liter. Dengan menggunakan dual flush toilet, dapat menghemat penggunaan air sebanyak 50\%. Menurut SNI 03-7065-2005 tentang Sistem Plambing, kebutuhan air manusia di kantor adalah 50 Liter/ hari (BSN 2005). Rata-rata pegawai di kantor melakukan kegiatan toilet sebanyak 4 kali. Apabila dalam 4 kali menggunakan dual flush toilet dengan tombol kecil, maka hanya membutuhkan air untuk flushing 16 liter air. 


\section{Pengurangan penggunaan air sumur dalam (deepwell)}

Penggunaan air sumur dalam di gedung dilakukan dalam keadaan darurat, yaitu saat air dari PDAM padam. Jika air dari PDAM padam, maka otomatis sumber air akan berpindah pada air sumur dalam. Sumur resapan berada di lantai basement. Salah satu fungsi dari sumur resapan yaitu meningkatkan jumlah air tanah. Dengan menambah volume air tanah, maka cadangan air tanah akan bertambah sehingga kualitas tanah menjadi lebih baik dan mempertinggi muka air tanah. Sistem kerja dari sumur resapan adalah air hujan dikumpulkan ke dalam sumur resapan, kemudian terus mengalir ke arah bawah tanah. Setelah itu, air hujan mengendap menjadi air tanah. Cadangan air tanah ini dapat menghemat penggunaan air tanah yang akan dimanfaatkan sebagai sumur deepwell.

\section{F. Sumber dan Siklus Material}

\section{Penggunaan material}

Penggunaan material di Menara Suara Merdeka berasal dari produk lokal yang didapatkan dari Semarang, Surabaya, dan Jakarta. Material bata ringan, kaca, keramik, cat, granit hemat energi dan produksi dari perusahaan yang telah mendapatkan label green. Material bangunan tahan lama, aman untuk kesehatan pengguna gedung dan dapat didaur ulang. Untuk freon AC menggunakan tipe R410A.

\section{Manajemen limbah}

Jenis sampah pada gedung adalah sampah kertas, makanan, dan plastik, namun sebagian besar hasil sampah adalah sampah tissue dan kertas. Sampah dikumpulkan oleh office boy dari masing-masing tenant, kemudian dikumpulkan oleh petugas cleaning service ke ruang penyimpanan sampah yang terdapat di lantai Basement. Pada gedung ini belum ada pemilahan sampah ataupun pengelolaan sampah. Sampah yang telah terkumpul di ruang loading sampah, kemudian diambil oleh petugas sampah dari kelurahan.

Sampah kemudian disalurkan kepada pihak ketiga yaitu pengepul sampah yang terletak di Jalan Tanggul, Semarang. Di pengepul sampah tersebut, diadakan pemilahan sampah yang masih dapat digunakan seperti kertas, plastik, kardus. Pengepul sampah ini merupakan pihak mandiri yang melakukan pemilahan sampah. Sampah pilahan dari pengepul selanjutnya dibeli oleh pengepul yang lebih besar di Jalan Kaligawe. Selanjutnya sampah didistribusikan ke pabrik untuk diolah menjadi barang baru dengan prinsip recycle. Contohnya sampah botol plastik dihancurkan menjadi serbuk plastik kemudian digunakan menjadi bahan pembuat ember.

Sampah yang tidak dapat digunakan kembali seperti tissue, sisa makanan, pecahan kaca diambil kembali oleh petugas sampah keluarahan untuk dikirim ke TPA (Tempat Pembuangan Akhir) di TPA Jatibarang, Semarang. Menurut pegawai Dinas Lingkungan Hidup Kota Semarang, di TPA Jatibarang terdapat beberapa cara pengolahan dan pemanfaatan sampah yaitu: sanitary landfill (penimbunan sampah dalam tanah), komposting, menghasilkan gas metana dari sampah organik, dan yang sedang dikembangkan yaitu pemanfaatan sampah menjadi gas metana sebagai Pembangkit Listrik Tenaga Sampah (PLTSA).

\section{G. Kenyamanan pengguna bangunan}

\section{Kendali Asap Rokok di Lingkungan}

Tidak ada ruang khusus merokok di gedung, namun karyawan merokok di lobby lantai Ground Floor maupun di gedung parkir. Tujuan dari area merokok adalah menghindarkan asap agar tak menyebar ke sudut ruangan lain, dan agar orang - orang yang tidak merokok tidak terganggu dengan asap rokok. Apabila membuat area merokok di dalam ruang, maka ruangan tersebut harus jauh dari ruangan lain. Supaya udara luar tetap 
masuk, dilengkapi dengan air supply. Diperlukan juga exhaust fan sebagai alat pertukaran udara. Fire alarm dan fire extinguisher digunakan sebagai antisipasi bahaya kebakaran.

\section{Kenyamanan udara dalam ruang}

Pemeliharaan dan perawatan AC untuk pencegahan kerusakan diagendakan setiap sebulan, tiga bulan, dan setahun. Dalam upaya memberikan kualitas sirkulasi udara dalam ruang yang bersih, dan nyaman, maka perlu dilakukan upaya perawatan berkala pada alatalat penghawaan buatan dalam ruang. Hal ini untuk mencegah terbentuknya lumut dan jamur yang dapat mengganggu kesehatan pengguna gedung. Zona kenyamanan termal pada iklim tropis adalah $24^{\circ} \mathrm{C}-26^{\circ} \mathrm{C}$ (Satwiko 2008). Suhu AC di setiap kantor tenant berbedabeda, sesuai dengan kebijakan kantor. Ada tenat yang yang mewajibkan AC harus dingin dengan suhu $16^{\circ} \mathrm{C}$, ada juga yang membebaskan karyawan mengatur suhu AC. Menggunakan AC dengan suhu yang sangat rendah, misalnya $16^{\circ} \mathrm{C}$, membuat AC bekerja lebih berat dan lebih boros energi. Suhu di dalam ruang yaitu $24^{\circ} \mathrm{C}-26^{\circ} \mathrm{C}$ ideal di Indonesia dengan keadaan iklim tropis. Selain adanya AC, terdapat fresh air supply yang menyediakan udara dari luar untuk dialirkan ke dalam bangunan. Fresh air supply berada di bagian luar gedung dan di tangga.

3. Kenyamanan pencahayaan dalam ruang

Cahaya diperlukan untuk mendapatkan kenyamanan visual. Ruangan kantor tetap terang dan nyaman digunakan untuk bekerja dengan pencahayaan alami yang masuk dari fasad kaca. Pencahayaan matahari mempunyai sifat dinamis karena perubahan gerak matahari dan awan di langit. Sehingga jumlah dan arah cahaya alami pada ruang dapat berubah, yang sering terjadi ialah menimbulkan silau (Pemerintah Provinsi DKI Jakarta 2012). Apabila karyawan merasa silau, maka akan menutupi jendela dengan vertical blind.

Menurut SNI 03-6575-2001 Tentang Tata Cara Perancangan Sistem Pencahayaan Buatan Pada Bangunan Gedung, daya listrik maksimal untuk pencahayaan kantor adalah 15 watt (SNI 2001). Sedangkan lampu yang digunakan di gedung menggunakan daya 18 watt. Namun karyawan tidak merasa silau apabila lampu menyala. Jenis lampu yang digunakan pada awal pengoperasian gedung adalah lampu jenis Fluorescent. Setelah ruangan diserahkan kepada pihak tenant, apabila lampu telah habis daya pakaiannya, maka penggantian lampu menjadi tanggung jawab tenant. Banyak tenant yang mengganti lampu menjadi jenis LED (Light Emitting Diode). Lampu LED memiliki daya waktu pijar 15.000 jam dengan kapasitas yang sama, serta hemat sampai dengan $80 \%$.

\section{Produktifitas kinerja karyawan}

Kantor green building memberikan lingkungan kerja dan tempat yang nyaman mengenai penghawaan, pencahayaan, dan kebisingan. Apabila lingkungan kantor tidak baik, maka dapat tercipta dampak sick building syndrom. Sick Building Syndrom terjadi ketika pengguna bangunan merasakan gangguan kesehatan akibat waktu yang dihabiskan selama berada di dalam sebuah bangunan. Suasana kerja di gedung telah memenuhi aspek kenyamanan dan kesehatan. Penghawaan udara di dalam ruang baik, udara wangi, pencahayaan tidak silau, dan tidak bising,

Pencahayaan alami dari sinar matahari masuk ke dalam ruangan, sehingga ruang kerja terang dan mengakibatkan karyawan dapat fokus bekerja dengan penerangan yang cukup. Masuknya sinar matahari juga dapat membunuh kuman atau bakteri yang ada di dalam ruang. Penghawaan buatan berupa AC terasa nyaman, sirkulasi udara juga tidak lembab, dan udara terasa segar. Tata ruang terbuka dengan penyekat rendah di kantor sehingga efek psikologis manusia tidak terasa sempit, atau terbatas. Penggunaan karpet kantor dapat membuat suasana kantor lebih berwarna dan menghadirkan rasa nyaman dan menghindarkan kebosanan. Selain itu karpet juga dapat meredam kebisingan dari suara hentakan kaki pegawai lainnya, dan terasa lembut apabila diinjak oleh kaki. Tingkat kehadiran karyawan adalah $90 \%$. faktor penyebab karyawan jarang tidak hadir atau sakit 
tidak hanya karena lingkungan kantor yang sehat, namun juga karena kebijakan manajemen kantor.

\section{H. Konstruksi Berkelanjutan}

Dalam pelaksanaan konstruksi bangunan, harus dapat meminimalkan dampak kerusakan bangunan dan meminimalkan penggunaan sumber daya alam. Kontraktor memiliki slogan "Go Green Construction". Pondasi yang digunakan adalah bored pile yang ramah lingkungan. Dalam konstruksi berkelanjutan, pondasi pile memiliki keunggulan tangible seperti meningkatkan produktivitas, lebih sedikit biaya operasional, hemat energi, dan lebih hemat pengeluaran karena tidak ada pekerjaan perbaikan akibat tidak menimbulkan efek getaran, serta pengurangan emisi karbon. Sedangkan keunggulan intangible adalah apresiasi pemilik bangunan, dan kepuasan kerja karyawan juga dicapai karena tercapainya konstruksi yang berkelanjutan (Saravanan 2011)

Pemakaian material menggunakan prinsip 3R yaitu reduce, reuse, dan recycle. Penghematan material menggunakan prinsip reuse. Yaitu sisa material dapat digunakan kembali. Sisa volume cor beton adalah $1 / 2 \mathrm{~m}^{3}$. Sisa cor beton tersebut digunakan untuk pembuatan car stopper dan perataaan jalan depan gedung. Bekisting yang digunakan berbahan baja. Sehingga dapat digunakan kembali pada proyek selanjutnya. Prinsip reduce dalam proses kontruksi yaitu mengurangi penggunaan material dengan memperbaiki sistem kinerja perusahaan kontraktor. Yaitu membuat perencanaan dengan cermat bagaimana penataan material pada bangunan, supaya tidak ada material yang terbuang (waste material). Rata-rata waste material keramik adalah 5\%. Namun dengan perencanaan, penyimpanan material yang baik, dan sistem pemasangan yang tepat, maka sisa material yang terbuang dapat kurang dari $5 \%$. Prinsip recycle yang dilakukan yaitu mengumpulkan sisa-sisa potongan besi untuk didaur ulang dengan bekerja sama dengan pihak ketiga yaitu pabrik besi.

\section{Sistem Pengelolaan Bangunan}

Pengelola bangunan memiliki target dan inovasi dalam maintenance bangunan untuk mewujudkan bangunan yang ramah lingkungan dan nyaman untuk pengguna gedung. Kewajiban dari pengelola gedung untuk mengadakan pemeliharaan dan perawatan bangunan. Saat ini, pihak pengelola sedang mengurus perpanjangan Sertifikat Lain Fungsi (SLF) bangunan. Pelatihan dan sertifikasi pegawai rutin diadakan untuk meningkatkan pengetahuan dan ketrampilan kerja. Data-data bangunan seperti dokumen As Built Drawing, spesifikasi teknis dan pemeliharaan peralatan utilitas tersimpan rapi untuk keperluan operasional dan perawatan gedung.

\section{J. Perilaku hemat energi}

Pencapaian green building tidak hanya secara fisik bangunan, namun juga terbentuk oleh komitemen penghuni gedung yang mendukung perilaku penghematan seperti penghematan energi listrik, penghematan air, pengurangan sampah dan kesadaran untuk menjaga agar lingkungan tetap terjaga. Penghematan listrik yang dilakukan yaitu mematikan AC, mode hibernate komputer, mematikan lampu saat siang hari. Penggunaan air di gedung ini digunakan untuk kegiatan toilet, berwudhu, dan pantry. Pengguna gedung menggunakan air seperlunya dan telah melakukan penghematan air. Karyawan gedung telah melakukan penghematan sampah misalnya menggunakan kertas pada bagian belakang digunakan untuk membuat konsep awal pekerjaan, digunakan untuk kertas fotokopi, atau digunakan untuk mencatat hasil rapat.

Kegiatan pengelolaan sampah kantor dapat dimulai dari kesadaran diri sendiri pegawai kantor untuk mengurangi atau memanfaatkan kembali sampah yang dihasilkan. Pihak pengelola gedung juga diharapkan dapat menyediakan sarana, prasarana tempat sampah yang terpisah antara sampah organik dan anorganik. 


\section{KESIMPULAN}

Penerapan green building di Menara Suara Merdeka yaitu: tepat guna lahan, fasad serta tata bangunan yang menyesuaikan keadaan iklim, AC VRV, pemanfaatan air limbah daur ulang, perlengkapan sanitair hemat air, peningkatan produktifitas kinerja, dan konstruksi berkelanjutan. Namun penerapan green building pada Menara Suara Merdeka belum sepenuhnya dilaksanakan yaitu konsumsi energi listrik yang melebihi standar bangunan green building. Rekomendasi dari hasil penelitian yaitu memanfaatkan sistem daur ulang air untuk flushing toilet, sistem manajemen sampah sebaiknya dilengkapi pemisahan sampah menurut jenisnya, pemanfaatan solar panel sebagai alternatif penghasil energi, dan diperlukan regulasi pembatasan waktu lembur karyawan dari manajemen gedung.

\section{DAFTAR REFERENSI}

BSN. 2005. SNI 03-7065-2005 Tata Cara Perencanaan Sistem Plambing. Jakarta: Badan Standardisasi Nasional.

F. Heinz, dan Suskiyatno, Bambang. 2007. Dasar-Dasar Arsitektur Ekologi Seri 1. Yogyakarta: Kansius yogyakarta.

GBCI. 2016. "Greenship Existing Building” 1.1: 1-14.

Karyono, Tri Harso. 2010. Green Architecture: Pengantar Pemahaman Arsitektur Hijau Di Indonesia. Jakarta: PT Raja Grafindo Persada.

Kementrian Pekerjaan Umum RI. 2006. "Peraturan Menteri Pekerjaan Umum No. 30/PRT/M/2006 Tentang Pedoman Teknis Fasilitas Dan Aksesibilitas Pada Bangunan Gedung Dan Lingkungan." Kementerian Pekerjaan Umum Republik Indonesia, II-1-II-65.

Manasseh, Leonard dan Cunliffe, Roger. 1962. Office Building. New York: Reinhold Publishing Corporation.

Mediastika, Christina Eviutami. 2013. Hemat Energi Dan Lestari Lingkungan Melalui Bangunan. Yogyakarta: Penerbit Andi.

Muhadjir, Noeng. 2000. Metode Penelitian Kulitatif. 4th ed. Yogyakarta: PT. Bayu Indra Grafika. Neufert, Ernest. 2002. Data Arsitek Jilid 2. 1st ed. Jakarta: Erlangga.

Pemerintah Provinsi DKI Jakarta. 2012. "Sistem Pencahayaan.” Panduan Pengguna Bangunan Gedung Hijau Jakarta 3 (38): 29.

Saravanan, Vk. 2011. "Cost Effective And Sustainable Practices For Piling Construction In The UAE.” Disertasi Heriot Watt University.

Satwiko, Prasasto. 2008. Fisika Bangunan. Yogyakarta: Penerbit Andi.

SNI. 2001. SNI 03-6575-2001 Tata Cara Perancangan Sistem Pencahayaan Buatan Pada Bangunan Gedung. Jakarta: Badan Standardisasi Nasional.

T.A. Fikriyah, P. Ary. 2016. "Konsep Green Building Pada Bangunan Kantor Spazio, Surabaya." Fakultas Teknik, Universitas Brawijaya, 1-8.

Vale, Brenda; V. Robert. 1991. Green Architecture Design Fo Sustainable Future. United Kingdom: Thames \& Hudson Ltd.

Wibisono, Adryanto Ibnu. 1999. "Pengaruh Glare Bidang Dinding Kaca Bangunan Tingkat Tinggi Terhadap Lingkungan.” Tesis Magister Teknik Arsitektur Universitas Diponegoro. Yeang, Ken. 1994. Designing with Nature. New York: Mc Grow-hill, inc. 